\title{
Feasibility Check for Carbon Emissions Estimation Method of G-TIES
}

\author{
Hyejung Hu, Jongdae Baek, Guenhee Lee, and Kwansub Noh
}

\begin{abstract}
The method for estimating carbon emissions across road life cycle is applied to G-TIES (green road technology investment evaluation system) being developed in Korea. G-TIES is an evaluation system that supports activities to gauge applicability of green road technology that reduces carbon emissions and to forecast benefits of application. First of all, the authors selected programs assessed to stand out among those already developed and are in use and qualitatively compared their functions in order to evaluate performance of the methodology adopted by G-TIES to calculate carbon emissions. In addition, G-TIES, ROADEO and Carbon Gauge Tool, which can calculate carbon emissions by entering general information on road projects, were used to calculate carbon amount emitted during construction of a road section in Korea. The values gained from ROADEO and Carbon Gauge Tool differed greatly from the value gained from G-TIES. Although further improvements need to be made in G-TIES in ways to include greater parts of carbon emission source in road works and reflect a wide variety of road construction conditions it is deemed to be more appropriate than other tools in calculating carbon emissions in road construction projects in Korea as its development is based on actual road constructions in the country.
\end{abstract}

Index Terms - Green house gas, carbon emissions, energy use, life cycle analysis (LCA), carbon footprint (CFP).

\section{INTRODUCTION}

Greenhouse gas is widely known as the major cause of global warming and climate change. The word carbon dioxide or carbon is frequently used as a substitute for greenhouse gas. Countries around the world have been taking aggressive actions to consume less energy and reduce greenhouse gas emissions since the United Nations framework convention on climate change (UNFCCC) was signed in 1992. Korean government also started to enforce Greenhouse Gas/Energy Target Management System since 2011 as part of the effort towards energy savings. The system designates "companies" that emit and consume certain amount of carbon and energy respectively and allots saving target to each company so that carbon emissions and energy consumption are kept in control. The system plans to cover greater number of companies on a

Manuscript received September 15, 2014; revised January 3, 2015. This paper is based on the work done under the Carbon Neutral Road Technologies Development project of the 2011 Construction Technology Innovation Program. The authors thank the Korea Agency for Infrastructure Technology Advancement (KAIA) and the Ministry of Land, Infrastructure and Transport (MOLIT) for the research support.

Hyejung Hu, Jongdae Baek, Guenhee Lee, and Kwansub Noh are with the Highway and Transportation Division, Korea Institute of Civil Engineering and Building Technology, 283 Goyangdae-Ro, Gyeonggi 411-712, Republic of Korea (e-mail: hhu@kict.re.kr, jdbaek@kict.re.kr, ghlee@kict.re.kr, ksno@kict.re.kr). gradual basis. This calls for a methodology to quantitatively calculate and control greenhouse gas emissions and energy consumption in the road sector, too.

Aware of such imperative, the Ministry of Land, Infrastructure \& Transport suggested "A guideline for estimating carbon emissions-road facilities [1]" as a solution to quantitatively calculate and control carbon amount emitted across the life cycle of social infrastructure facilities. In the road sector, study on "The development of carbon-neutral road technologies", which is the R\&D task of MOLIT developed a methodology to calculate carbon emissions across a road life cycle and this is the basis for developing G-TIES (green road technology investment evaluation system), which gauges applicability of green road technology that reduces carbon emissions and forecasts benefits of application. G-TIES is being developed in ways to make a forecast and evaluation in three aspects. First, it evaluates carbon reduction effect of green road technologies. Second, it analyzes benefits of applying alternatives to carbon reduction. Third, it analyzes carbon emissions as-is of roads across the country and future value. As its name indicates, G-TIES development aims at supporting evaluation on whether or not it is apt to develop green technologies.

However, securing reliability in the methodology to calculate carbon emissions is highly critical since it is the basis for system evaluation. As such, this study focuses on evaluating functionality of carbon emission estimation methodologies being developed for G-TIES and already developed in similar programs, and on exploring solutions for further improvement of G-TIES. G-TIES is being developed to calculate carbon emissions during road construction, maintenance and operation across whole road life cycle but this study restricted only methodology in calculating carbon emissions during construction as the evaluation scope. This study looks at programs evaluated to be outstanding among peers and gives a summary of their comparative functions. It then calculates carbon emissions generated during construction of a certain road section in Korea by using carbon emissions calculation methodology by G-TIES, ROADEO [2], and Carbon Gauge Tool [3] and compared the outputs from the three tools. General information, data entered into each program, results from the tools, and analysis on the selected road are summarized below.

\section{Methodology COMPARISON}

Studies on methodologies to calculate greenhouse gas emissions in road transportation sector have been performed from a long time ago in both Korea and abroad. Many calculation programs are available, too. Studies to calculate 
carbon emissions across a road life cycle have increased only in recent years and available programs are few and far between. The methodology known as Carbon Footprint (CFP) calculates greenhouse gas emissions during road construction stage and carbon amount constantly emitted during maintenance and operation after construction. In construction and maintenance stages, carbon emissions are calculated based on materials and equipments used during construction. In operation stage, they're calculated based on electricity and fuel consumed for operating road facilities. Carbon emissions can also be calculated by carbon emissions factors, which are estimated for each material type, fuel type consumed and fuel efficiency of each equipment.

Even so, this is not easy to calculate carbon emissions from road construction since types of materials and equipment are too wide and combinations are of wide variety as well. Also, it is impossible to calculate carbon emissions in the road planning stage before a detailed road design is done. This is why G-TIES developed two different level carbon emissions calculation program. One is the function to estimate carbon emissions when precise volumes of materials and equipment types and usages is available and the other is to do so only based on rough information i.e. type of road, number of lanes and length of road section by type of road structures. For the latter method, G-TIES research team collects and analyzes construction records of existing roads and calculates representative carbon emissions intensity in order to estimate carbon emission intensity of the top-level construction type.

According to World Bank Report [4], which gives a comparison of 12 existing programs, most of the tools were never used in Asia and have poor applicability to other regions. The report selected CHANGER [5] developed by International Road Federation (IRF), Highways Agency Carbon Tool [6] by South Australia, and Carbon Gauge Tool [3] by Australia's VicRoad as good reference programs, and used them as a reference to develop ROADEO [2].

As a starter, functions of G-TIES, ROADEO, Carbon Gauge Tool, Highways Agency Carbon Tool, Highways Agency Carbon Tool and GreenDOT [7] were compared. As shown in Table I, ROADEO provides two analysis modes just like G-TIES. When a user enters general information on road construction project, ROADEO provides two input options. One is to run an internal model to calculate the amount of materials needed and equipments used for the particular road project and the other is to let the user enter volume information in detail. Carbon Gauge Tool's logic is similar to ROADEO's option but requires users to enter more detailed information on a road construction project in the first mode. Highway Agency Carbon tool and GreenDOT provide options to enter detailed volume. GreenDOT, in particular, is developed in ways to compare benefits of applying green technologies.

Table II compares carbon generators included in each methodology across the road life cycle. The degree to including carbon emission sources varies greatly by methodology. The most types of carbon emission sources can be taken into account in Highway Agency Carbon Tool and GreenDOT but most of the relevant volume needs to be entered directly by the user. In GreenDOT, in particular, input is not based on each road life cycle, which means the user cannot make the input intuitively.

TABLE I: FUNCTIONALITIES CHECK 1 - INPUT OPTIONS

\begin{tabular}{|c|c|c|c|c|c|}
\hline \multirow[t]{2}{*}{ Input options } & \multicolumn{5}{|c|}{ Carbon Footprint Tools } \\
\hline & G-TIES & ROADEO & $\begin{array}{l}\text { Carbon } \\
\text { Gauge } \\
\text { Tool }\end{array}$ & $\begin{array}{l}\text { Highways } \\
\text { Agency Carbon } \\
\text { Tool }\end{array}$ & Green DOT \\
\hline $\begin{array}{l}\text { Overall project } \\
\text { information }\end{array}$ & $\mathrm{O}$ & $\mathrm{O}$ & $\mathrm{O}$ & $X$ & X \\
\hline $\begin{array}{l}\text { Detailed Project } \\
\text { quantities }\end{array}$ & $\mathrm{O}$ & $\mathrm{O}$ & $X$ & $\mathrm{O}$ & $\mathrm{O}$ \\
\hline
\end{tabular}

TABLE II: FUNCTIONALITIES CHECK 2 - SCOPE OF CARBON GENERATORS

\begin{tabular}{|c|c|c|c|c|c|c|}
\hline \multirow{2}{*}{$\begin{array}{l}\text { Road } \\
\text { Life Cycle }\end{array}$} & \multirow{2}{*}{$\begin{array}{l}\text { GHG } \\
\text { Generator }\end{array}$} & \multicolumn{5}{|c|}{ Carbon Footprint Tools } \\
\hline & & G-TIES & ROADEO & $\begin{array}{l}\text { Carbon } \\
\text { Gauge } \\
\text { Tool }\end{array}$ & $\begin{array}{l}\text { Highways } \\
\text { Agency } \\
\text { Carbon } \\
\text { Tool }\end{array}$ & $\begin{array}{l}\text { Green } \\
\text { DOT }\end{array}$ \\
\hline Design & - & $X$ & $X$ & $X$ & $X$ & $\mathrm{X}$ \\
\hline \multirow[t]{5}{*}{ Construction } & Materials & $\mathrm{O}$ & $\mathrm{O}$ & $\mathrm{O}$ & $\mathrm{O}$ & $\Delta$ \\
\hline & $\begin{array}{l}\text { Work } \\
\text { Equipment }\end{array}$ & $\mathrm{O}$ & $\mathrm{O}$ & $\mathrm{O}$ & $\mathrm{O}$ & $\Delta$ \\
\hline & Transport & $\mathrm{X}$ & $\mathrm{O}$ & $\mathrm{O}$ & $\mathrm{O}$ & $\Delta$ \\
\hline & $\begin{array}{l}\text { Land-Use } \\
\text { Change }\end{array}$ & $\mathrm{X}$ & $\mathrm{O}$ & $\mathrm{O}$ & $\mathrm{X}$ & $\mathrm{X}$ \\
\hline & $\begin{array}{l}\text { Waste } \\
\text { Removal }\end{array}$ & $\mathrm{X}$ & $\mathrm{X}$ & $\mathrm{X}$ & $\mathrm{O}$ & $\mathrm{X}$ \\
\hline \multirow[t]{5}{*}{ Maintenance } & Materials & $\mathrm{O}$ & $X$ & $\mathrm{O}$ & $\mathrm{O}$ & $\Delta$ \\
\hline & $\begin{array}{l}\text { Work } \\
\text { Equipment }\end{array}$ & $\mathrm{X}$ & $\mathrm{X}$ & $\mathrm{X}$ & $\mathrm{O}$ & $\Delta$ \\
\hline & Transport & $\mathrm{X}$ & $\mathrm{X}$ & $\mathrm{X}$ & $\mathrm{O}$ & $\Delta$ \\
\hline & $\begin{array}{l}\text { Waste } \\
\text { Removal }\end{array}$ & $\mathrm{X}$ & $\mathrm{X}$ & $\mathrm{X}$ & $\mathrm{O}$ & $\mathrm{X}$ \\
\hline & $\begin{array}{l}\text { Traffic } \\
\text { Management }\end{array}$ & $\mathrm{O}$ & $\mathrm{X}$ & $\mathrm{X}$ & $\mathrm{X}$ & $\mathrm{O}$ \\
\hline \multirow[t]{2}{*}{ Operation } & $\begin{array}{l}\text { Road Utility } \\
\text { Operation }\end{array}$ & $\mathrm{O}$ & $X$ & $\mathrm{O}$ & $X$ & $\mathrm{O}$ \\
\hline & $\begin{array}{l}\text { On-Road } \\
\text { vehicles }\end{array}$ & $\mathrm{X}$ & $X$ & $\mathrm{O}$ & $\mathrm{X}$ & $\mathrm{O}$ \\
\hline
\end{tabular}

O: include, $\mathrm{X}$ : not include, and $\Delta$ :possible (not straight forward inputs)

In construction, G-TIES takes into account amount of materials and equipment used while ROADEO and Carbon Gauge Tool consider changes in carbon emissions during material transportation and in carbon absorption caused by changes in plantation due to road construction. Later, some of factors which were not included in G-TIES should be considered to be added.

Overall, most of the tools use identical logic in calculating carbon emissions and allow the user to enter or adjust actual volume so that new changes caused by numerous conditions in road projects can be reflected properly, thereby generate more reliable output. But, it does not seem appropriate to use other countries' tools as they are since countries have different road design standards and different emission factors by material, fuel efficiency and fuel type of equipment used.

\section{CASE STUDY}

If the volume entered and emission intensity is the same, 
there will not be a difference in the outputs in methodologies that calculate emissions by entering volume in detail. By contrast, carbon emissions calculation by entering rough information on road project will result in different outputs since the standards used to calculate volumes is different, which is the case in ROADEO and Carbon Gauge Tool. The study selected as specific road for a case study and compared outputs calculated with the two tools above based on rough information and outputs by G-TIES.

\section{A. Study Site}

The study site is part of national road no. 36 (Boryeong Uljin), which is shown in Fig. 1. National road \#36, which connects Cheongju-si and Cheongwon-gun, is congested and has high risk of car accidents. The study site, which is a national road, was accordingly built to ensure smooth traffic, reduce accident rate and serve as the main arterial road in the area.

A new route was added instead of improving the existing road. Total length of the four-lane road is $13.4 \mathrm{~km}$, design speed is $80 \mathrm{~km} / \mathrm{h}$ and road width is $20.0 \mathrm{~m}$ (width of car lane $3.5 \mathrm{~m}$, width of median $2.0 \mathrm{~m}$, width of shoulder $2.0 \mathrm{~m}$, width of marginal strip $0.50 \mathrm{~m}$, width of protection shoulder $0.5 \mathrm{~m}$ ).

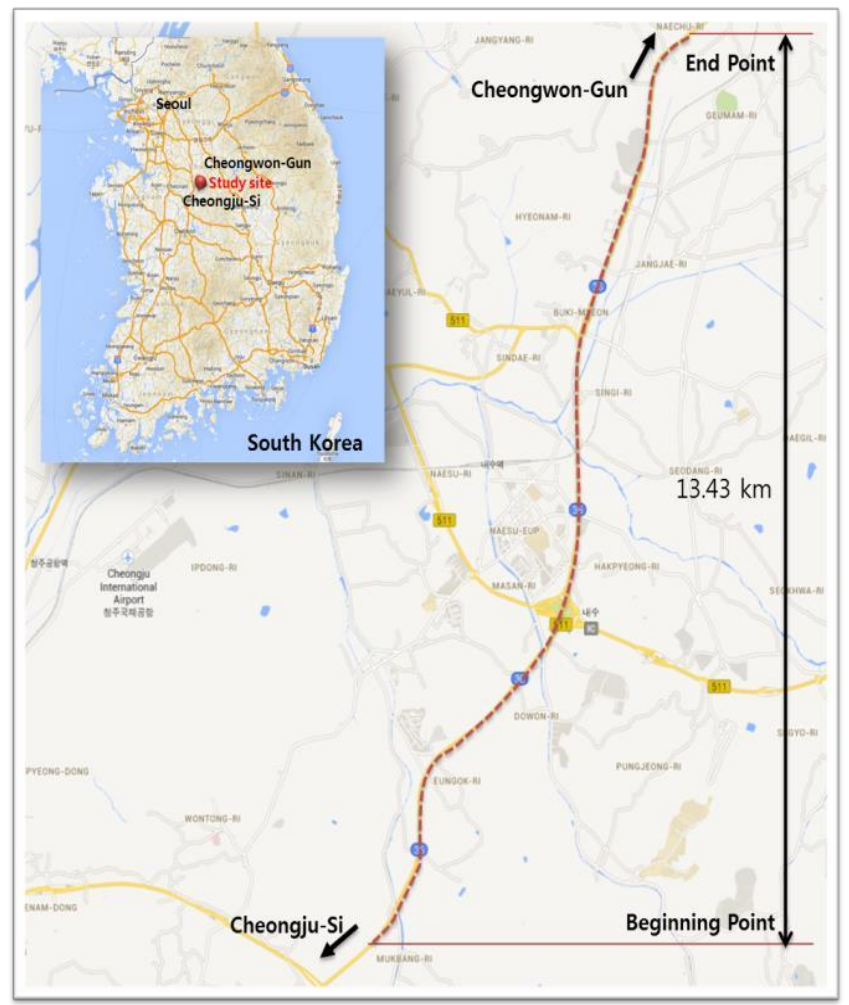

Fig. 1. Location of study site (map source: Google).

TABLE III: INPUT DATA FOR G-TIES

\begin{tabular}{lllr}
\hline \hline Road Life Cycle & Work Category & \multicolumn{2}{c}{$\begin{array}{l}\text { Length } \\
(\mathrm{km})\end{array}$} \\
\hline Construction & Earthwork & & 11.43 \\
& Drainage & & 11.43 \\
& & Bridge & 1.4457 \\
& Structure & Tunnel & 0.55 \\
& Pavement & Others & 11.43 \\
& & Road Safety & 11.43 \\
& Road & furniture & 11.43 \\
& Furniture & Others & 11.43 \\
& & (Noise wall) & \\
\hline \hline
\end{tabular}

TABLE IV: INPUT DATA FOR ROADEO

\begin{tabular}{|c|c|c|}
\hline Designation & Input Value & unit \\
\hline Work Type & New alignment & list \\
\hline Road type & National road & list \\
\hline Alignment length & 13,400 & $\mathrm{~m}$ \\
\hline Number of lanes & 4 & $\mathrm{u}$ \\
\hline Lane width & 3.50 & $\mathrm{~m}$ \\
\hline Median width & 2.00 & $\mathrm{~m}$ \\
\hline Median type & Paved & list \\
\hline Shoulder width & 2.00 & $\mathrm{~m}$ \\
\hline Shoulder type & Paved & list \\
\hline Existing cross section width & 0.00 & $\mathrm{~m}$ \\
\hline General longitudinal profile & $26.00 \%$ & $\%$ \\
\hline $\begin{array}{l}\text { Length of road in mountainous } \\
\text { terrain as a percentage of road } \\
\text { project length }\end{array}$ & $50.00 \%$ & $\%$ \\
\hline $\begin{array}{l}\text { Length of road in urban areas as a } \\
\text { percentage of road project length }\end{array}$ & $0.00 \%$ & $\%$ \\
\hline $\begin{array}{l}\text { Length of existing longitudinal } \\
\text { drainage as a percentage of road } \\
\text { project length }\end{array}$ & $0.00 \%$ & $\%$ \\
\hline $\begin{array}{l}\text { Length of existing cross drainage } \\
\text { as a percentage of requirement }\end{array}$ & $0.00 \%$ & $\%$ \\
\hline $\begin{array}{l}\text { Parameter reflecting the balance } \\
\text { between cut and fill }\end{array}$ & $100.00 \%$ & $\%$ \\
\hline $\begin{array}{l}\text { Volume of rocky soil as a } \\
\text { percentage of volume of soil (in } \\
\% \text { ) }\end{array}$ & $76.50 \%$ & $\%$ \\
\hline $\begin{array}{l}\text { Area where subgrade has to be } \\
\text { treated with hydraulic binders }\end{array}$ & $100.00 \%$ & $\%$ \\
\hline $\begin{array}{l}\text { Volume of embankment to be } \\
\text { treated as a percentage of the } \\
\text { volume of cut reused }\end{array}$ & $100.00 \%$ & $\%$ \\
\hline $\begin{array}{l}\text { Number of bridges to be widened } \\
\text { as a percentage of number of } \\
\text { bridges }\end{array}$ & $0.00 \%$ & $\%$ \\
\hline Subgrade strength class & $\begin{array}{l}\text { Standard Soil } \\
{[8 \%-15 \%]}\end{array}$ & list \\
\hline Expected traffic volumes & $\begin{array}{l}\text { Medium traffic }[17 \text { to } \\
30 \text { Million ESA] }\end{array}$ & list \\
\hline Pavement structure type & $\begin{array}{l}\text { Bituminous } \\
\text { pavement on } \\
\text { granular materials }\end{array}$ & list \\
\hline Overlay structure type & 0.00 & list \\
\hline Type of barrier material & Steel & list \\
\hline $\begin{array}{l}\text { Type of structure (standard } \\
\text { bridges) }\end{array}$ & $\begin{array}{l}\text { Concrete (reinforced } \\
\text { / prestressed) }\end{array}$ & list \\
\hline Type of structure (major bridges) & $\begin{array}{l}\text { Concrete (reinforced } \\
\text { / prestressed) }\end{array}$ & list \\
\hline Type of structure (wall) & Reinforced concrete & list \\
\hline Length of tunnel & 550 & $\mathrm{~m}$ \\
\hline
\end{tabular}

\section{B. Input Data}

Table III to Table V presents information on the study site entered in G-TIES, ROADEO and Carbon Gauge Tool respectively. Execution design reports sand design configurations of the study site were referred to for the input.

Rough information required in G-TIES includes road type, road width, total length and extension of structures as shown in Table III. As described above, the study site is a four-lane national road $20.0 \mathrm{~m}$ wide. Total length is $13.4 \mathrm{~km}$ out of which length of bridge section is $1.4457 \mathrm{~km}$ and tunnel 
section is $0.55 \mathrm{~km}$. Length of section requiring earthwork, drainage, structure, pavement and road furniture are in Table III. Emissions can be calculated by entering section length of each construction type since carbon emission intensity in which $\mathrm{tCO}_{2} / \mathrm{km}$ suitable for each construction type and road hierarchy is the unit is available.

TABLE V: INPUT DATA FOR CARBON GAUGE_CONSTRUCTION

\begin{tabular}{|c|c|c|c|c|}
\hline Work Category & & & Input Value & Unit \\
\hline \multirow{4}{*}{ Earthwork } & Stripe and respread topsoil & & & 0 Total volume $\left(\mathrm{m}^{3}\right)$ \\
\hline & Cut to spoil & & & 0 Total volume $\left(\mathrm{m}^{3}\right)$ \\
\hline & Cut to fill & & & $1,465,035$ Total volume $\left(\mathrm{m}^{3}\right)$ \\
\hline & Import and place filling & & & 516,694 Total volume $\left(\mathrm{m}^{3}\right)$ \\
\hline \multirow{3}{*}{ Drainage } & Kerbing & upright curve and gutter & & 1.4457 Total Length (km) \\
\hline & Culverts (Pipes) & Medium 450-750 RCP & & 3.167 Total Length $(\mathrm{km})$ \\
\hline & Culverts (Box) & $300 \times 1200 \mathrm{RCBC}$ & & 1.791 Total Length $(\mathrm{km})$ \\
\hline \multirow{4}{*}{ Structure } & Bridge & Precast reinforced concrete beam & & $\begin{array}{l}1.4457 \text { Total Length }(\mathrm{km}) \\
20 \text { Width }(\mathrm{m})\end{array}$ \\
\hline & Tunnel & & & N/A - \\
\hline & & & & Concrete Type \\
\hline & Others (Retaining walls) & & & $\begin{array}{l}0.195 \text { Total Length }(\mathrm{km}) \\
0.78 \text { Height }(\mathrm{m})\end{array}$ \\
\hline \multirow{4}{*}{ Pavement } & Full Depth Asphalt* & & & $272,829 \mathrm{~m}^{2}$ \\
\hline & Plain Concrete & $\mathrm{T} 15 \mathrm{~cm}$ & & $9,893 \mathrm{~m}^{2}$ \\
\hline & Plain Concrete & $\mathrm{T} 20 \mathrm{~cm}$ & & $67 \mathrm{~m}^{2}$ \\
\hline & Plain Concrete & $\mathrm{T} 30 \mathrm{~cm}$ & & $37,015 \mathrm{~m}^{2}$ \\
\hline \multirow{3}{*}{ Road Furniture } & Road Safety furniture & $\mathrm{W}$ beam barrier & & 23.498 Total Length (km) \\
\hline & Noad sarety rumsture & F type Barrier & & 9.905 Total Length (km) \\
\hline & Others (Noise wall) & Steel plate & & 0.776 Total Length $(\mathrm{km})$ \\
\hline
\end{tabular}

*250mm Hot Mix Asphalt, 150mm Cement Treated aggregate, 150mm Aggregate-Quarried (Can be modified)

TABLE VI: Estimation Results FROM the SELECTED Methods

\begin{tabular}{|c|c|c|c|c|c|c|c|c|c|c|c|}
\hline \multirow{3}{*}{ Road Life Cycle } & \multicolumn{2}{|l|}{ Work Category } & \multicolumn{9}{|c|}{ Carbon Emissions $\left(\mathrm{t} \mathrm{CO}_{2}-\mathrm{e}\right)$} \\
\hline & & & \multicolumn{3}{|l|}{ ROADEO } & \multicolumn{3}{|c|}{ Carbon Gauge Tool } & \multicolumn{3}{|l|}{ G-TIES } \\
\hline & & & Material & Fuel & \begin{tabular}{|l|} 
Sub \\
Total
\end{tabular} & Material & Fuel & \begin{tabular}{|l|} 
Sub \\
Total
\end{tabular} & Material & Fuel & \begin{tabular}{|l} 
Sub \\
Total \\
\end{tabular} \\
\hline \multirow{8}{*}{ Construction } & \multicolumn{2}{|l|}{ Earthwork } & 6,600 & 1,500 & 8,100 & - & 9,451 & 9,451 & 900 & 5,503 & 6,403 \\
\hline & \multicolumn{2}{|l|}{ Drainage } & 1,200 & 30 & 1,230 & 1,784 & \multirow{7}{*}{6,098} & \multirow{7}{*}{63,739} & 10,625 & 167 & 10,792 \\
\hline & \multirow{3}{*}{ Structure } & Bridge & \multirow{3}{*}{11,900} & \multirow{3}{*}{810} & \multirow{3}{*}{12,710} & 34,671 & & & 18,899 & 1,562 & 20,461 \\
\hline & & \begin{tabular}{|l|} 
Tunnel \\
\end{tabular} & & & & - & & & 7,773 & 823 & 8,596 \\
\hline & & \begin{tabular}{|l}
$\begin{array}{l}\text { Others } \\
\text { (walls) }\end{array}$ \\
\end{tabular} & & & & 50 & & & 884 & 141 & 1,025 \\
\hline & \multicolumn{2}{|l|}{ Pavement } & 2,000 & 1,000 & 3,000 & 16,247 & & & 9,176 & 2,073 & 11,249 \\
\hline & \multirow{2}{*}{ Road Furniture } & $\begin{array}{l}\text { Road Safety } \\
\text { furniture }\end{array}$ & \multirow{2}{*}{1,500} & \multirow{2}{*}{10} & \multirow{2}{*}{1,510} & 3,529 & & & 52 & 63 & 115 \\
\hline & & \begin{tabular}{|l}
$\begin{array}{l}\text { Others } \\
\text { (Noise wall) }\end{array}$ \\
\end{tabular} & & & & 1,360 & & & 1,223 & 248 & 1,471 \\
\hline \multicolumn{3}{|l|}{ Total } & \multicolumn{3}{|c|}{26,550} & \multicolumn{3}{|c|}{73,190} & \multicolumn{3}{|c|}{60,113} \\
\hline
\end{tabular}

Table IV is information on the study site entered in ROADEO. It demands geographical information, regional information, soil information and traffic volume, which affect decisions on civil engineering and road pavement thickness. Information demanded by ROADEO is more detailed than what G-TIES demands. It also requires selection of type of pavement and structure. But, it is configured in ways to enter ratio over precise figure. When the precise selections cannot be found in the lists, closest options were selected. ROADEO asks the length of tunnel, but it doesn't ask the length of bridge. The user manual notes that an average $125 \mathrm{~m}$ in bridge length is applied for the calculation.

Table $\mathrm{V}$ shows information on the study site entered in Carbon Gauge. Unlike the other two methodologies, it demands material volumes to be entered directly but the number of input items is smaller than those that require detailed volume information since total volume information in the top level is entered in this case. The value corresponding to input window packaged by construction type is entered and type of facilities can be selected, too. In addition, it is configured in ways to allow the user to adjust thickness by each pavement layer to presumably reflect changes in carbon emissions when different materials and construction methods are used depending on type of road facilities.

\section{RESULTS}

Table VI is the summary of outputs from the three tools. Total emissions in ROADEO are 26,550 $\mathrm{tCO}_{2}-\mathrm{e}$, which is significantly lower than carbon emissions in the two other tools. In the other two methodologies, carbon emissions associated with equipment accounted for the lion's share in the case of earthwork (100\% in Carbon Gauge) while carbon emissions from materials took the majority in ROADEO.

Emissions from drainage, structure and pavement were far lower than that of the other two tools. Total emissions in Carbon Gauge Tool are 73,190 $\mathrm{tCO}_{2}-\mathrm{e}$, which does not differ 
much from the emissions in G-TIES. It could not be compared with G-TIES by construction type since emissions from consuming fuel in equipment are not broken up by construction type.

Emissions calculated are lower compared to that in G-TIES in drainage and pavement while function to consider tunnel construction does not exist yet. Emissions from bridge construction are calculated relatively higher than other tools. Table VI also shows that emissions from installation safety facilities are calculated at a high level.

\section{CONCLUSION}

This study selected the existing programs evaluated for their high performance and qualitatively compared their functions in order to evaluate performance of calculating carbon emissions method of G-TIES. ROADEO, Carbon Gauge Tool and G-TIES all of which can calculate carbon emissions with rough information on road projects were applied to compare carbon emissions during the construction stage of a certain road section in Korea.

G-TIES should build on its functions to include more carbon emission sources on roads. It will become a more reliable tool if it reflects a broader variety of road project conditions. However one of its advantages is simpler input items compared to other models to gain general output.

It is also deemed to be fit for Korea. Most of other methodologies are not developed in Asia and even ROADEO developed for Asia are not customized to road construction standards, climate and soil conditions of Korea, which challenges efforts to calculate a highly reliable carbon emissions.

This study is limited in that it failed to find a concrete analysis on why carbon emissions hugely vary between ROADEO, Carbon Gauge Tool and G-TIES. Causes of the wide variance may be identified if precise volume by material and equipment calculated in each model and emission intensity are compared in the future. Also, a study to compare and analyze methods to calculate emissions in the maintenance and operation stages is necessary. Such a study will hopefully suggest the amount of efforts needed to reduce carbon emissions in road, gauge benefits of carbon emission reduction technologies and determine the right amount of investment.

\section{REFERENCES}

[1] MLTM, A Guideline for Estimating Carbon Emissions-Road Facilities, Ministry of Land, Transport and Maritime Affairs, 2011.

[2] ROADEO (Road Emissions Optimization). (September 2014). A Toolkit for Greenhouse Gas Emissions Mitigation in Road Construction and Rehabilitation. [Online]. Available: https://www.astae.net/publication/roadeo-\%E2\%80\%93-road-emissio ns-optimization-toolkit-greenhouse-gas-emissions-mitigation-road

[3] A. Dilger, C. Riley, S. Young, J. Bengtsson, and B. Kneppers, Greenhouse Gas Assessment Workbook for Road Projects, Transport Authorities Greenhouse Group Australia and New Zealand (TAGG), 2011.

[4] Greenhouse Gas Emissions Mitigation in Road Construction and Rehabilitation-A Toolkit for Developing Countries, The Word Bank Group Asia Sustainable and Alternative Energy Program, 2011.

[5] Calculator for Harmonised Assessment and Normalisation of Greenhouse-gas Emissions for Roads. (September 2014). [Online]. Available: http://www.irfghg.org/index.php
[6] Greenhouse Gas Accounting Tool for Construction Guideline, Department of Planning Transport and Infrastructure, Government of South Austrailia, 2012

[7] F. Gallivan, J. Ang-Olson, and A. Papson, Greenhouse Gas Mitigation Measures for Transportation Construction, Maintenance, and Operations Activities, Part of NCHRP Project 25-25, Task 58, National Cooperative Highway Research Program, Transportation Research Board, 2010.

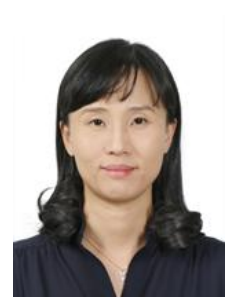

Hyejung $\mathrm{Hu}$ is a senior researcher at Korea Institute of Civil Engineering and Building Technology (KICT). She received her bachelor of engineering degree in urban engineering from Hongik University in 1999 She decided to focus on studying transportation engineering and studied for her master degree at the University of Seoul which is one of the great schools in transportation engineering in Korea. After receiving her master degree in 2001, she worked at the Government of Seoul City for two years. Her duty was improving the Seoul traffic signal operation systems. She went to North Carolina State University in 2003 and earned her Ph.D. degree in 2009. After two years of her post doc period at the Institute for Transportation Research and Education in NCSU, she came back to Korea and began to work at KICT. She is currently involved in various researches on sustainability of transportation.

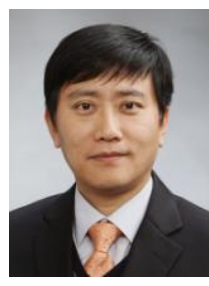

Jongdaeg Baek received his bachelor of engineering degree from the University of Seoul in 1999. He continued his study as a graduate student in the Department of Transportation Engineering at the same university and received his master of engineering degree in 2001. After two years of work experience as a researcher at the Korea Institute of Civil Engineering and Building Technology (KICT), he went to Raleigh, North Carolina to pursue a Ph.D. degree in civil engineering at North Carolina State University in 2003 and received his Ph.D. degree in 2007. After four years of his work as a post doc. at the Highway Safety Research Center at the University of North Carolina, he came back to Korea and has been working at Highway \& Transportation Research Division in KICT as a senior researcher. His areas of experience include road geometry improvement, road safety countermeasure evaluation, and recently sustainable road strategies.

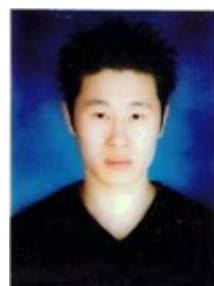

Guenhee Lee is an associate researcher at Korea Institute of Civil Engineering and Building Technology (KICT). He received his bachelor of engineering degree in urban engineering from Daejin University in 2007. He received his master of engineering degree in urban engineering from Hanyang University in 2009. He decided to focus on studying transportation engineering after receiving his master degree and is taking a Ph.D. degree course at the same university. He is currently involved in various researches on sustainability of roads.

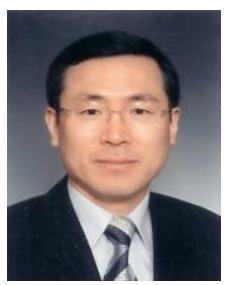

Kwansub Noh is a senior research fellow at the Highway \& Transportation Research Division of the KICT and has been working on the project of Development of Carbon Neutral Road Technologies as a group leader. He received his bachelor degree in civil engineering at the University of Chosun in 1981 master degree at the University of Dankook in 1987, and his Ph.D. degree in urban engineering at the University of Seoul in 1997. He is a vice president of the Korean Society of Road Engineers and a member of Korean Professional Engineers Association, Korean Society of Transportation, and Korean Society of Civil Engineers. His areas of experience include road design guide, road safety policy and engineering, roadscape design, and recently sustainable road engineering. 